\title{
Mango Tolerance to Reduced Oxygen Levels in Controlled Atmosphere Storage
}

\author{
Renar J. Bender, ${ }^{1}$ Jeffrey K. Brecht, ${ }^{2}$ Steven A. Sargent, and Donald J. Huber \\ Horticultural Sciences Department, University of Florida, P.O. Box 110690, Gainesville, FL 32611 -0690
}

\begin{abstract}
AdDitional INDEX words. Mangifera indica, anaerobic respiration, carbon dioxide, color, ethanol, ethylene, hypoxia
Abstract. 'Haden' and 'Tommy Atkins' mangoes (Mangifera indica L.) were stored in air, 2, 3, 4 or $5 \mathrm{kPa} \mathrm{O}_{2}$ plus $\mathrm{N}_{2}$, or $25 \mathrm{kPa} \mathrm{CO}$ plus air for 14 days at $15^{\circ} \mathrm{C}$ or 21 days at $12^{\circ} \mathrm{C}$, respectively, then in air for 5 days at $20^{\circ} \mathrm{C}$ to determine their tolerance to reduced $\mathrm{O}_{2}$ levels for storage times encountered in typical marine shipments. All low $\mathrm{O}_{2}$ treatments reduced mature green mango respiration $\left(\mathrm{CO}_{2}\right.$ production), however, elevated ethanol production occurred in 2 and $3 \mathrm{kPa} \mathrm{O}_{2}$ storage, with the levels two to three times higher in 'Tommy Atkins' than 'Haden'. In contrast, 'Haden' fruit at the onset of the climacteric also accumulated ethanol in $4 \mathrm{kPa} \mathrm{O}_{2}$ and produced 10 to 20 -fold more ethanol in 2 and $3 \mathrm{kPa} \mathrm{O}_{2}$ than preclimacteric fruit. While there were no visible injury symptoms, off flavor developed in mature green fruit at $2 \mathrm{kPa} \mathrm{O}_{2}$ and in ripening initiated fruit at 2 and $3 \mathrm{kPa} \mathrm{O}_{2}$. Ethanol production was not affected by storage in $25 \mathrm{kPa} \mathrm{CO}_{2}$. Ethylene production was reduced slightly by low $\mathrm{O}_{2}$, however, 'Haden' fruit also showed a residual inhibitory effect on ethylene production after 2 or $3 \mathrm{kPa} \mathrm{O}_{2}$ storage, while 'Tommy Atkins' fruit stored in $2 \mathrm{kPa} \mathrm{O}_{2}$ produced a burst of ethylene upon transfer to air at $20^{\circ} \mathrm{C}$. Fruit firmness, total sugars, and starch levels did not differ among the treatments, but 2,3 or 4 $\mathrm{kPa} \mathrm{O}_{2}$ and $25 \mathrm{kPa} \mathrm{CO}$ maintained significantly higher acidity than $5 \mathrm{kPa} \mathrm{O}_{2}$ or air. The epidermal ground color responded differently to low $\mathrm{O}_{2}$ and high $\mathrm{CO}_{2}$ in the two mango cultivars. Only $2 \mathrm{kPa} \mathrm{O}_{2}$ maintained 'Haden' color better than air, while all low $\mathrm{O}_{2}$ levels maintained 'Tommy Atkins' color equally well and better than air. $\mathrm{High}^{\mathrm{CO}_{2}} \mathrm{was}$ more effective than low $\mathrm{O}_{2}$ in maintaining 'Haden' color, but had about the same effect as low $\mathrm{O}_{2}$ on 'Tommy Atkins'. Results indicate that preclimacteric 'Haden' and 'Tommy Atkins' mango fruit are able to tolerate $3 \mathrm{kPa} \mathrm{O}_{2}$ for 2 or 3 weeks at 12 to $15^{\circ} \mathrm{C}$ and that tolerance to low $\mathrm{O}_{2}$ decreases as mangoes ripen. Results also show that low $\mathrm{O}_{2}$ and high $\mathrm{CO}_{2}$ affect mango ripening differentially.
\end{abstract}

Many beneficial effects of controlled atmosphere (CA) storage are attributed to reduction of $\mathrm{O}_{2}$ concentrations. Some of the positive effects of optimum low $\mathrm{O}_{2}$ storage atmospheres on fruit crops are reduced ethylene production and respiratory activity, better flavor retention, slower softening rates, slower green color loss, and maintenance of organic acid levels (Thompson, 1998). In contrast to these positive results, undesirable responses can occur when more extreme $\mathrm{O}_{2}$ atmospheres are used in attempts to extend storage life, alleviate physiological disorders, and for insect disinfestation or control of postharvest pathogens. These undesirable responses consist mainly of discoloration and off flavor development (Thompson, 1998). It is well established that, under hypoxia, the activities of pyruvate decarboxylase and alcohol dehydrogenase (ADH) increase in plants, leading to accumulation of acetaldehyde and ethanol (Kennedy et al., 1992).

The $\mathrm{O}_{2}$ concentration at which the transition from aerobic to anaerobic respiration occurs has been termed the anaerobic compensation point (ACP) by Boersig et al. (1988). Further studies to determine the lowest $\mathrm{O}_{2}$ concentration at which anaerobic respiration is absent or avoided has indicated that the ACP, at least in some species, is strongly influenced by the physiological age of the commodity (Boersig et al., 1988) and by the storage temperature (Beaudry et al., 1992). Moreover, tolerance to low $\mathrm{O}_{2}$ environments is species dependent (Kennedy et al., 1992) and tolerance to various exposure times is characteristic for each commodity (Ke et al., 1993).

Received for publication 21 Dec. 1999. Accepted for publication 3 July 2000 Florida Agricultural Experiment Station journal series R-06683. This paper is a portion of a Ph.D. Dissertation submitted by R.J.B. The cost of publishing this paper was defrayed in part by the payment of page charges. Under postal regulations, this paper therefore must be hereby marked advertisement solely to indicate this fact.

${ }^{1}$ Current address: Dept. of Horticulture and Silviculture, Univ. Federal Rio Grande do Sul, C.P. 776, 91501-970, Porto Allegre, RS, Brasil.

${ }^{2}$ To whom reprint requests should be addressed.
A review of the history of modified atmosphere and CA storage of tropical fruits, including mangoes, has recently been published (Yahia, 1998). As with most CA research over the years, the vast majority of CA studies with mango have been conducted with the goal of determining the atmosphere and temperature combination that allows the longest possible storage life to be attained. The general conclusion of these studies has been that there are only modest or no benefits from CA storage for mangoes. This is due mainly to limited disease control by the moderate $\mathrm{O}_{2}(5 \mathrm{kPa})$ and $\mathrm{CO}_{2}(5 \mathrm{kPa})$ levels tolerated by mango fruit over extended storage periods at temperatures $\left(12\right.$ to $\left.15^{\circ} \mathrm{C}\right)$ required to avoid chilling injury. More recently, Yahia and coworkers (Yahia et al. 1989; Yahia and Tiznado-Hernandez, 1993; Yahia and Vazquez-Moreno 1993) used short exposure times at relatively high temperature to evaluate insecticidal atmospheres for potential disinfestation of mangoes infested with Tephritid fruit flies species. They found that 'Keitt' mangoes tolerated 0.2 to $0.5 \mathrm{kPa} \mathrm{O}_{2}$ for $5 \mathrm{~d}$ at $20{ }^{\circ} \mathrm{C}$ with no off-flavors or other signs of injury, and ripened normally after the low- $\mathrm{O}_{2}$ treatments. Similarly, Bender et al. (1994) found that 'Kent' and 'Tommy Atkins' mangoes tolerated and benefited from a CA of $3 \mathrm{kPa} \mathrm{O}_{2}$ plus $25 \mathrm{kPa} \mathrm{CO}_{2}$ if storage time at $12{ }^{\circ} \mathrm{C}$ was limited to 3 weeks, however only $\mathrm{CO}_{2}$ levels were varied in those tests.

In international commerce, most mangoes are picked before the onset of ripening and many are shipped by ocean in refrigerated marine containers with transit times on the order of 2 to 3 weeks. Other than the time spent in transit, there is little or no commercial storage of mangoes longer than a few days. Virtually all mangoes imported into the United States are treated with $46^{\circ} \mathrm{C}$ water for 65 to $90 \mathrm{~min}$ (depending on variety and fruit weight) for insect disinfestation (U.S. Deprtment of Agriculture, 1998), which has been reported to accelerate some aspects of ripening, especially skin color change, although inhibiting softening and decay (McGuire, 1991; Nyanjage et al., 1998). For mangoes destined for transport over long distances, there is a tendency to 
harvest the fruit before full maturity in an attempt to prolong storage life, which, ironically, increases the likelihood of chilling injury, hot water injury, and poor flavor quality (Johnson et al., 1997; Medlicott et al., 1990). Use of CA during transport could potentially increase storage life sufficiently to allow marineshipped, fully mature mangoes to be delivered to export markets with consistently acceptable quality. Our objective was thus to determine the tolerance of mangoes to reduced $\mathrm{O}_{2}$ concentrations for 2 to 3 weeks at normal shipping temperatures, and to evaluate fruit ripening during and after transfer from $\mathrm{CA}$.

\section{Materials and Methods}

Plant material. 'Haden' mangoes from Peru and 'Tommy Atkins' mangoes from Brazil were obtained from a commercial importer in Homestead, Florida. The fruit were harvested at normal commercial maturity for refrigerated marine shipment to Florida (i.e., mature green) and handled at the origin under normal commercial conditions, including hot water insect quarantine treatment, coating with a commercial formulation of carnauba wax, and precooling to $15^{\circ} \mathrm{C}$ before shipment by airplane in insulated containers to Florida. The experiments with each cultivar were replicated once using fruit from different shipments. Upon arrival in Florida ( 2 or $3 \mathrm{~d}$ after harvest), the mangoes were transported from Homestead to Gainesville by refrigerated truck at $12^{\circ} \mathrm{C}(7 \mathrm{~h}$ in transit). In Gainesville, fruit that were fully mature, uniform in ground color, and free from defects were selected, immediately placed in glass jars, and transferred to the designated storage room. Initial fruit maturity was RS1 (mature green) as described by Miller et al. (1986), except for an additional experiment using 'Haden' mangoes with more advanced ground color development (RS3; Miller et al., 1986) that was conducted to investigate the effect of low $\mathrm{O}_{2}$ on ripening initiated (tree-ripe) fruit.

Controlled atmospheres. Individual 'Haden' fruit were placed in 1.75-L glass jars, with six replicates per treatment and sampling time, and held in a flow-through system at $15^{\circ} \mathrm{C}$ for 14 d. Air, delivered by a compressor, was mixed with nitrogen $\left(\mathrm{N}_{2}\right)$ from a cylinder to produce $2,3,4$, and $5 \mathrm{kPa} \mathrm{O}_{2}$ treatments. One control treatment was air in the flow-through system, and a $25 \mathrm{kPa}$ $\mathrm{CO}_{2}$ control was obtained by combining $\mathrm{CO}_{2}$ with air (resulting in $\approx 15.6 \mathrm{kPa} \mathrm{O}_{2}$ ). We had previously identified $25 \mathrm{kPa} \mathrm{CO}_{2}$ as the highest concentration tolerated by mangoes during 3 weeks storage (Bender et al., 1994). The same treatments were applied to 'Tommy Atkins' mangoes held in 10-L glass jars for $21 \mathrm{~d}$ at 12 ${ }^{\circ} \mathrm{C}$. In the latter experiments, four fruit per replicate and four replicates per treatment and sampling time were used. Flow rates were selected based on fruit weight such that accumulation of respiratory $\mathrm{CO}_{2}$ would remain below $0.5 \mathrm{kPa}$ and were adjusted as required. Gas concentrations were confirmed and monitored by gas chromatography. The air and the gas mixtures were humidified by bubbling through water before entering the jars containing the fruit. 'Haden' and 'Tommy Atkins' were stored at different temperatures and for different times based on preliminary work indicating shorter storage life and lower tolerance to low temperature in the former compared to the latter cultivar. Different replicate numbers reflected availability of uniform maturity fruit.

Gas Chromatography. Daily during the storage period, 0.5$\mathrm{mL}$ headspace samples were removed from each jar and injected into gas chromatographs (GCs) to measure ethanol, ethylene, and $\mathrm{CO}_{2}$ production. Ethylene and $\mathrm{CO}_{2}$ production were not measured during storage in $25 \mathrm{kPa} \mathrm{CO}_{2}$ due to difficulty in accurately measuring respiratory $\mathrm{CO}_{2}$ accumulation and previous results showing that ethylene production is undetectable during storage in $25 \mathrm{kPa} \mathrm{CO}$. After the storage period, the mangoes were transferred to air at $20^{\circ} \mathrm{C}$ for $5 \mathrm{~d}$. During the $5 \mathrm{~d}$ of ripening, the fruit were sealed periodically in the jars and, after $1 \mathrm{~h}, 0.5-\mathrm{mL}$ headspace samples were removed for ethanol and ethylene production and respiration rate determinations in all treatments.

Ethanol was determined on a GC (model 5890; HewlettPackard, Avondale, Pa.) equipped with a $1520 \times 3.12 \mathrm{~mm} 80 / 120$ mesh Carbopack B column at $140^{\circ} \mathrm{C}$. The injector and the flame ionization detector temperatures were $200{ }^{\circ} \mathrm{C}$. Ethylene was determined on a GC (model 10A10; Photovac, Thornhill, Ontario, Canada) with a photoionization detector and $760 \times 3.12 \mathrm{~mm}$ activated alumina column. The temperatures of the injector, detector, and column were not controlled, but both equilibrated at a few degrees above ambient as a consequence of heat from the ultraviolet source. The $\mathrm{CO}_{2}$ levels were determined on a gas partitioner GC (model 1200; Fisher Scientific, Pittsburgh, Pa.) equipped with a $1966 \times 3.12 \mathrm{~mm} 80 / 100$ mesh Porapak Q column at $60{ }^{\circ} \mathrm{C}$. The injector and the thermal conductivity detector temperatures were $90^{\circ} \mathrm{C}$.

Firmness AND COMPOSITION. Measurements of fruit firmness, titratable acidity, total sugars, and starch content were made initially, at transfer from storage at 12 or $15^{\circ} \mathrm{C}$, and after $5 \mathrm{~d}$ in air at $20^{\circ} \mathrm{C}$. 'Haden' firmness was measured using a Cornell firmness device (Hamson, 1952) as modified by Gull (1987). A $1 \mathrm{~kg}$ weight was applied to unpeeled fruit and deformation in millimeters was recorded after $5 \mathrm{~s}$. An Instron Universal Testing Machine (model 1132; Canton, Mass.) equipped with a 50-kg load cell and an 11-mm-diameter Magness-Taylor test probe was used to measure 'Tommy Atkins' firmness. The probe was applied to peeled fruit at $10 \mathrm{~cm} \cdot \mathrm{min}^{-1}$ until the bioyield force was reached. In both cases, two measurements were made on opposing equatorial sides of each fruit. After the firmness measurements, the mesocarp tissue was homogenized and used for determinations of titratable acidity, total sugars, and starch content. Titratable acidity was determined by titrating mango juice to a $\mathrm{pH}$ endpoint of 8.2 and was expressed as percent citric acid. Total alcohol-soluble sugars were determined colorimetrically by the phenol-sulfuric method as described by Dubois et al. (1956). Starch content was determined as described in Bergsma and Brecht (1992), entailing overnight enzymic digestion of the alcohol insoluble material at $37{ }^{\circ} \mathrm{C}$ with $\alpha$-amylase and amyloglucosidase (Sigma, St. Louis, Mo.), followed by measurement of the resulting soluble sugars by the phenol-sulfuric method. The fruit were also evaluated for evidence of external and internal injury and evaluated informally for off flavor development at the end of each experiment.

Color measurements. Epidermal color determinations were made initially, at transfer from storage at 12 or $15^{\circ} \mathrm{C}$, and after 5 d in air at $20^{\circ} \mathrm{C}$ using a portable chroma meter (CR-200; Minolta Corp., Ramsey, N.J.) calibrated to a white standard plate(CRA43) in the $\mathrm{L}^{*} \mathrm{c} * \mathrm{~h} *$ color system (Lightness, chroma, and hue angle, respectively). Measurements were made using diffuse illumination and $0^{\circ}$ viewing angle under CIE illuminant $\mathrm{C}$ conditions (McGuire, 1992). For each fruit, two random measurements were taken at the distal end and one measurement at the equator on the shaded side (to avoid the red anthocyanin pigment "blush"). Flesh color was determined only with 'Tommy Atkins' mangoes. Two measurements were taken on opposing equatorial sides of each fruit after removing the epidermis. 
EXPERIMENTAL DESIGN AND STATISTICAL ANALYSIS. The experiments were conducted using a completely randomized design with fruit numbers as described above. Statistical analysis was done using SAS for PC (SAS Institute Inc., Cary, N.C.) with data subjected to analysis of variance (PROC ANOVA) and LSD values calculated for $P=0.05$.

\section{Results and Discussion}

RESPIRATION. Respiration rates in both cultivars were lower in the low- $\mathrm{O}_{2}$ treatments compared to air control fruit, but the patterns were quite different (Fig. 1A and B). There was a clear distinction among the low- $\mathrm{O}_{2}$ treatments in 'Haden' fruit and, for the 2,3 , and $4 \mathrm{kPa} \mathrm{O}_{2}$ treatments, respiration rates were already reduced significantly by the first day of storage. In contrast, the low- $\mathrm{O}_{2}$ effect was less and there was little difference among the 2,3 , and $4 \mathrm{kPa} \mathrm{O}_{2}$ treatments for 'Tommy Atkins' fruit; additionally, it took more than 1 week for $\mathrm{CO}_{2}$ production in the $5 \mathrm{kPa} \mathrm{O}$ treatment to fall below that of the air control. After transfer to air at $20{ }^{\circ} \mathrm{C}, \mathrm{CO}_{2}$ production in all the treatments showed similar sharp increases. There was no indication from $\mathrm{CO}_{2}$ production during storage that the $\mathrm{O}_{2}$ levels used in this study induced anaerobic respiration.

Ethanol PRODuction. Ethanol production rates increased during storage at $15^{\circ} \mathrm{C}$ in 'Haden' fruit held in 2 or $3 \mathrm{kPa} \mathrm{O}_{2}$ (Fig. 1C) with a 5-fold higher level after 2 weeks in $2 \mathrm{kPa} \mathrm{O}_{2}$ than in 3 $\mathrm{kPaO}_{2}$, but did not change in fruit held in air or 4 or $5 \mathrm{kPaO}_{2}$. In 'Tommy Atkins' (Fig. 1D), ethanol production increased gradually with decreasing $\mathrm{O}_{2}$ concentrations in the storage atmosphere at $12{ }^{\circ} \mathrm{C}$ and did not change in the air control fruit. Ethanol production rates in the $25 \mathrm{kPa} \mathrm{CO}_{2}$ treatment were similar to the control fruit for both cultivars. After transfer to air at $20{ }^{\circ} \mathrm{C}$, ethanol production continued to increase in 'Haden' fruit from 2 $\mathrm{kPa} \mathrm{O}_{2}$ storage, almost tripling to a peak of $\approx 1500 \mu \mathrm{L} \cdot \mathrm{kg}^{-1} \cdot \mathrm{h}^{-1}$, but did not change in fruit from $3 \mathrm{kPa} \mathrm{O}_{2}$ and increased little (4 and $5 \mathrm{kPaO}_{2}$ and air) or not at all $\left(25 \mathrm{kPaCO}_{2}\right)$ in the other treatments. Ethanol production increased in 'Tommy Atkins' fruit from all treatments, including the air control, after transfer to air at $20^{\circ} \mathrm{C}$.

'Tommy Atkins' fruit from the $2 \mathrm{kPa} \mathrm{O}_{2}$ treatment reached a peak of ethanol production more than twice that of 'Haden' fruit from the same treatment and 'Tommy Atkins' fruit from the other low- $\mathrm{O}_{2}$ treatments all reached peak ethanol production rates at 20 ${ }^{\circ} \mathrm{C}$ that were at least equal to that of 'Haden' fruit from $2 \mathrm{kPa} \mathrm{O}_{2}$ storage. The 'Tommy Atkins' air control and $25 \mathrm{kPa} \mathrm{CO}_{2}$-stored fruit also increased ethanol production at $20^{\circ} \mathrm{C}$, to $\approx 600$ to 700 $\mu \mathrm{L} \cdot \mathrm{kg}^{-1} \cdot \mathrm{h}^{-1}$.

It is interesting that the elevated ethanol production rates in 'Haden' and 'Tommy Atkins' mangoes in the low $\mathrm{O}_{2}$ treatments were not accompanied by corresponding increases in $\mathrm{CO}_{2}$ production, as is observed typically in tissues undergoing anaerobiosis. Although ADH activity seems clearly to have been induced by the low $\mathrm{O}_{2}$ treatments, as evidenced by increased ethanol production, it appears that energy demand was low in these mango fruit, limiting carbon flux through the glycolytic pathway. In a separate experiment, 'Haden' mangoes that had initiated climacteric respiration at the beginning of storage (Fig. 2A) had much higher ethanol production rates during low- $\mathrm{O}_{2}$ storage (Fig. 2B) than the 'Haden' fruit discussed above, which entered storage at a less ripe stage (Fig. 1A and C). The latter fruit remained preclimacteric during the 2-week storage period, while the more advanced fruit went through the climacteric rise in respiration and ripened during storage, but still with no indication of anaerobic
$\mathrm{CO}_{2}$ production (Fig. 2A). Although the climacteric 'Haden' fruit produced much higher ethanol than the preclimacteric 'Haden' fruit, they were still less sensitive to low $\mathrm{O}_{2}$ concentrations than 'Tommy Atkins' fruit, in that $5 \mathrm{kPa} \mathrm{O}_{2}$ storage still did not cause any increase in ethanol production compared to the air control (Fig. 2B). Thus, both cultivar and ripeness stage appear to be involved in influencing ethanol production in mangoes.

ETHYLENE PRODUCTION. The pattern of ethylene production in 'Haden' fruit during storage at $15^{\circ} \mathrm{C}$ was similar to the pattern of
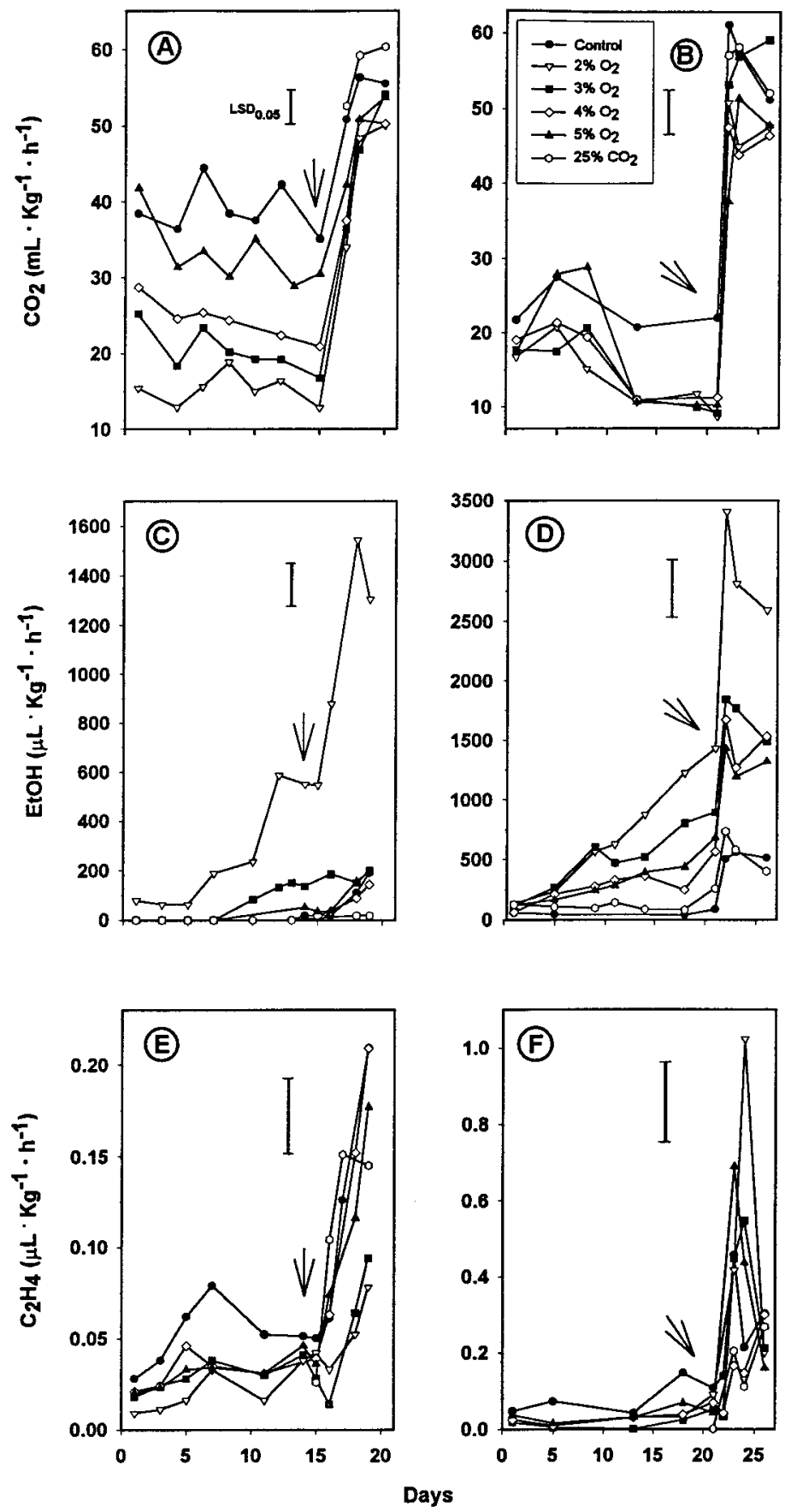

Fig. 1. (A and $\mathbf{B})$ respiration, $(\mathbf{C}$ and $\mathbf{D})$ ethanol, and (E and $\mathbf{F})$ ethylene production rates of mature-green $(\mathbf{A}, \mathbf{C}$, and $\mathbf{E})$ 'Haden' and $(\mathbf{B}, \mathbf{D}$, and $\mathbf{F})$ 'Tommy Atkins' mangoes during $14 \mathrm{~d}$ at $15^{\circ} \mathrm{C}$ or $21 \mathrm{~d}$ at $12^{\circ} \mathrm{C}$, respectively, in air (control) or controlled atmospheres, plus $5 \mathrm{~d}$ in air at $20^{\circ} \mathrm{C}$. Arrows indicate transfer to air at $20^{\circ} \mathrm{C}$. Data are means of six ('Haden') or four ('Tommy Atkins') observations. 

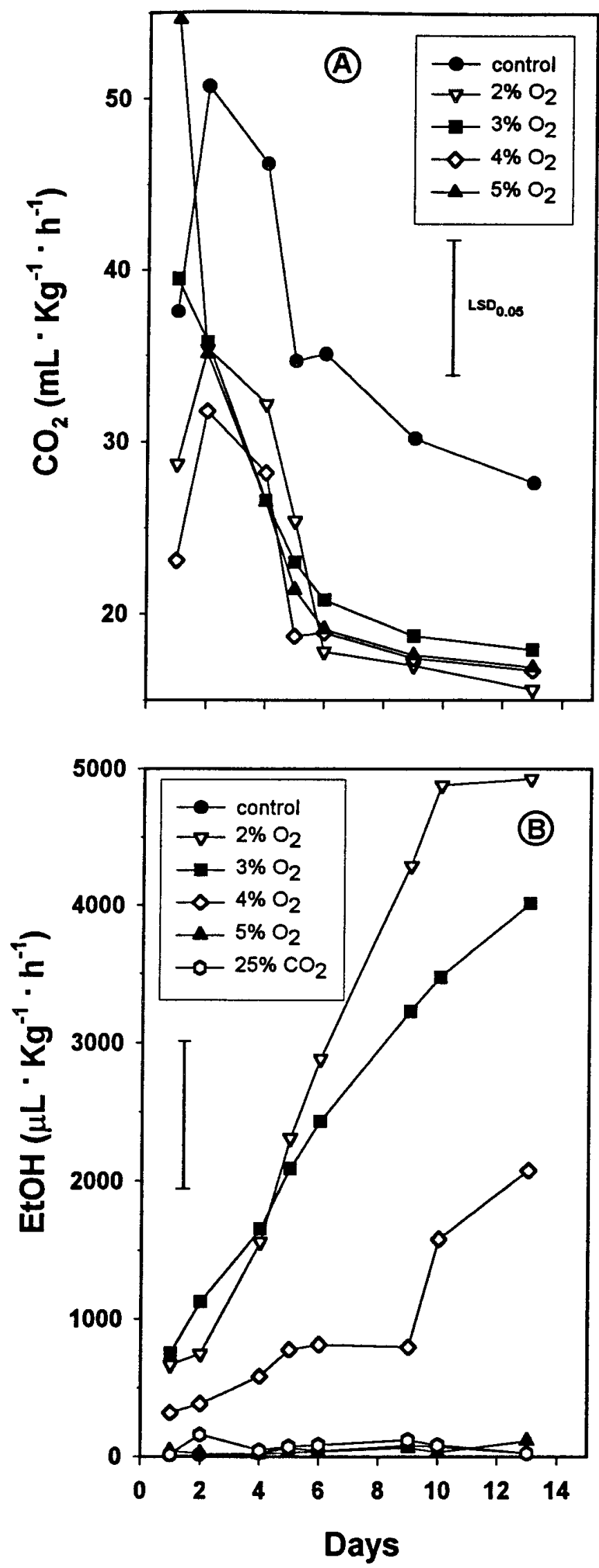

Fig. 2. (A) respiration and (B) ethanol production rates of ripening-initiated 'Haden' mangoes stored in air (control) or controlled atmospheres for $13 \mathrm{~d}$ at 15 ${ }^{\circ} \mathrm{C}$. Data are means of six ('Haden') or four ('Tommy Akins') observations.
$\mathrm{CO}_{2}$ production, with air control fruit producing more ethylene than fruit from the low- $\mathrm{O}_{2}$ treatments, but the rates of ethylene production were extremely low (Fig. 1E). In 'Tommy Atkins' fruit, ethylene production was also low with not much difference among the air and low- $\mathrm{O}_{2}$ treatments during storage at $12^{\circ} \mathrm{C}$ (Fig. $1 \mathrm{~F})$. We observed previously that $25 \mathrm{kPa} \mathrm{CO}_{2}$ almost completely inhibited ethylene production by mature-green 'Tommy Atkins' mangoes during storage for $21 \mathrm{~d}$ at $12{ }^{\circ} \mathrm{C}$ (Bender et al., 1995). After transfer to air at $20^{\circ} \mathrm{C}$, ethylene production by both cultivars increased significantly in all treatments, however, 'Haden' fruit showed a residual inhibitory effect of the reduced $\mathrm{O}_{2}$ atmospheres. Ethylene production by 'Haden' fruit from the two lowest $\mathrm{O}_{2}$ treatments remained lower than that of control fruit after transfer to air at $20^{\circ} \mathrm{C}$. In contrast, ethylene production by 'Tommy Atkins' fruit from the $2 \mathrm{kPa} \mathrm{O}_{2}$ treatment produced a burst of ethylene at $20^{\circ} \mathrm{C}$ that was more than twice that of the air control.

Firmness AND COMPosition. Fruit of both cultivars softened during storage, but neither low $\mathrm{O}_{2}$ nor high $\mathrm{CO}_{2}$ reduced softening compared to air storage, and further softening after transfer to air at $20^{\circ} \mathrm{C}$ was rather limited (data not presented). Similarly, sugar and starch levels were not significantly affected by storage in low $\mathrm{O}_{2}$ or high $\mathrm{CO}_{2}$ compared to air in either cultivar; starch breakdown was essentially complete in all treatments at the time of transfer to $20^{\circ} \mathrm{C}[(0.1 \%$ fresh weight $(\mathrm{FW})]$ and, although sugar levels declined by $\approx 30 \%$ to $50 \%$ during the $5 \mathrm{~d}$ at $20^{\circ} \mathrm{C}$, there was no difference between air and CA-stored fruit (data not presented). In contrast, titratable acidity of both 'Haden' and 'Tommy Atkins' mangoes was significantly affected by the low $\mathrm{O}_{2}$ and high $\mathrm{CO}_{2}$ treatments during storage. At transfer from 12 or $15^{\circ} \mathrm{C}$, $\mathrm{CA}$-stored fruit had about twice the acid level of the air-stored fruit; after $5 \mathrm{~d}$ in air at $20^{\circ} \mathrm{C}$, the $25 \mathrm{kPa} \mathrm{CO}_{2}$ treatment and all of the low- $\mathrm{O}_{2}$ treatments except $5 \mathrm{kPa} \mathrm{O}_{2}$ maintained significantly higher acidity than the air control (Table 1). These results suggest that higher respiration rates by the air control fruit during storage at 12 or $15^{\circ} \mathrm{C}$ were probably due to greater utilization of organic acids as substrates for glycolysis compared to CA-stored fruit. However, sugar consumption was equal in both air and CA-stored fruit, suggesting that glycolysis was running unhindered, perhaps causing an accumulation of pyruvate and subsequently reduced oxidative phosphorylation in the lower $\mathrm{O}_{2}$ treatments due to less energy demand. Increased amounts of pyruvate could then have stimulated its own reduction to ethanol as indicated by Ke et al.

Table 1. Titratable acidity in mature-green 'Haden' and 'Tommy Atkins' mangoes stored for $14 \mathrm{~d}$ at $15^{\circ} \mathrm{C}$ or $21 \mathrm{~d}$ at $12^{\circ} \mathrm{C}$, respectively, in air or controlled atmospheres, plus $5 \mathrm{~d}$ in air at $20^{\circ} \mathrm{C}$.

\begin{tabular}{|c|c|c|c|c|}
\hline \multirow{3}{*}{$\begin{array}{l}\text { Storage } \\
\text { atmosphere }\end{array}$} & \multicolumn{4}{|c|}{$\begin{array}{l}\text { Titratable acidity } \\
\text { (\% FW citric acid) }\end{array}$} \\
\hline & \multicolumn{2}{|c|}{ Haden } & \multicolumn{2}{|c|}{ Tommy Atkins } \\
\hline & At transfer & $+5 \mathrm{~d}$ in air & At transfer & $+5 \mathrm{~d}$ in air \\
\hline$\overline{\text { Air }}$ & $0.83^{\mathrm{z}}$ & 0.61 & 0.54 & 0.36 \\
\hline $2 \mathrm{kPa} \mathrm{O}$ in $\mathrm{N}_{2}$ & 2.84 & 2.03 & 1.18 & 1.14 \\
\hline $3 \mathrm{kPa} \mathrm{O}_{2}$ in $\mathrm{N}_{2}$ & $\mathrm{ND}^{\mathrm{y}}$ & 1.68 & 1.48 & 1.02 \\
\hline $4 \mathrm{kPa} \mathrm{O}_{2}$ in $\mathrm{N}_{2}^{2}$ & ND & 1.28 & 0.95 & 0.81 \\
\hline $5 \mathrm{kPa} \mathrm{O}_{2}^{2}$ in $\mathrm{N}_{2}^{2}$ & 1.93 & 0.86 & 1.09 & 0.60 \\
\hline $25 \mathrm{kPa} \mathrm{CO}_{2}$ in air & 1.80 & 1.38 & 1.12 & 0.75 \\
\hline $\mathrm{LSD}_{0.05}$ & \multicolumn{2}{|c|}{0.31} & \multicolumn{2}{|c|}{0.32} \\
\hline
\end{tabular}

${ }^{\bar{z}}$ Data are means of six ('Haden') or four ('Tommy Atkins') observations. yNo data. 

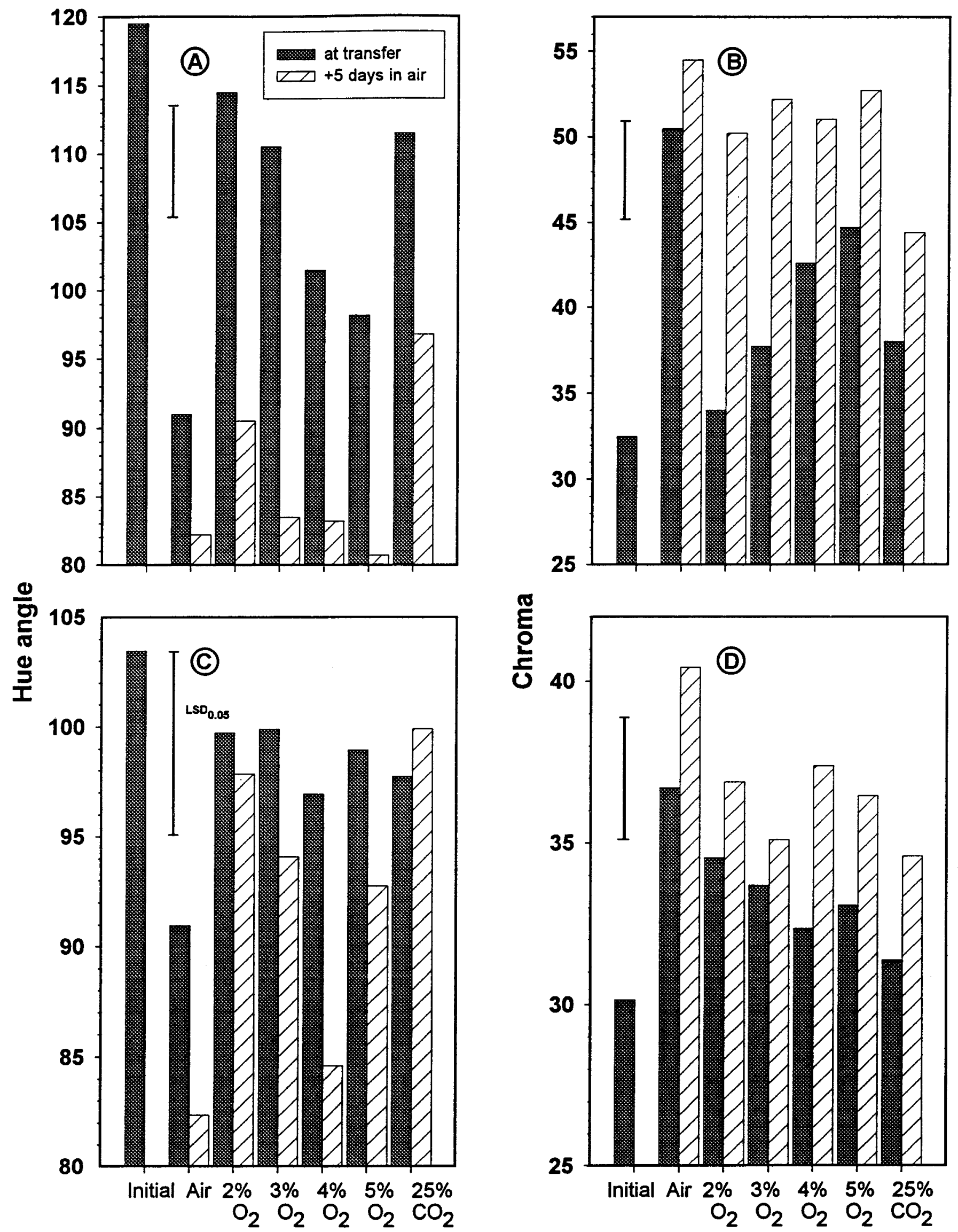

Fig. 3. (A and $\mathbf{C})$ hue angle and (B and $\mathbf{D})$ chroma values of mature-green (A and $\mathbf{B})$ 'Haden' and $(\mathbf{C}$ and $\mathbf{D})$ 'Tommy Atkins' mangoes during $14 \mathrm{~d}$ at $15{ }^{\circ} \mathrm{C}$ or 21 $\mathrm{d}$ at $12{ }^{\circ} \mathrm{C}$, respectively, in air (control) or controlled atmospheres, plus $5 \mathrm{~d}$ in air at $20^{\circ} \mathrm{C}$. Data are means of six ('Haden') or four ('Tommy Atkins') observations. 
(1993; 1995). This could explain the accumulation of ethanol without the corresponding elevated $\mathrm{CO}_{2}$ production that would be expected if anaerobiosis was induced.

Color Changes. Despite being greener initially than the 'Tommy Atkins' fruit, 'Haden' air control fruit underwent a significant color change during the 2 weeks of storage at $15^{\circ} \mathrm{C}$ (Fig. 3A and B). 'Haden' mangoes from the low- $\mathrm{O}_{2}$ treatments showed an $\mathrm{O}_{2}$ concentration-dependent response for both epidermal hue and chroma during the CA storage period with all of the low- $\mathrm{O}_{2}$ treatments maintaining larger hue angles and lower chroma values than the air control. The epidermal hue and chroma of 'Haden' fruit from the $25 \mathrm{kPa} \mathrm{CO}_{2}$ treatment at transfer were similar to the values of those from the 2 and $3 \mathrm{kPa} \mathrm{O}_{2}$ treatments. Like 'Haden', 'Tommy Atkins' fruit stored in air at $12{ }^{\circ} \mathrm{C}$ also changed hue more than fruit stored in low $\mathrm{O}_{2}$ or $25 \mathrm{kPaCO}_{2}(\mathrm{Fig}$. $3 \mathrm{C}$ and $\mathrm{D})$, but unlike 'Haden' there was no difference in hue angle or chroma among the CA treatments at the time of transfer to air at $20^{\circ} \mathrm{C}$. For 'Tommy Atkins', only the fruit in the $25 \mathrm{kPa}$ $\mathrm{CO}_{2}$ treatment maintained a significantly lower epidermal chroma value than the air control at the time of transfer to $20^{\circ} \mathrm{C}$ with the low $\mathrm{O}_{2}$ treatments having intermediate chroma values (Fig. 3D).

After transfer to air at $20^{\circ} \mathrm{C}$, there was an intense color change in air control fruit of both cultivars (Fig. 3). While the $25 \mathrm{kPa} \mathrm{CO}_{2}$ treatment strongly inhibited further changes in epidermal hue and chroma in both mango cultivars following transfer to air at $20^{\circ} \mathrm{C}$, the ability of the low- $\mathrm{O}_{2}$-stored 'Haden' and 'Tommy Atkins' fruit to develop epidermal color after transfer to air at $20{ }^{\circ} \mathrm{C}$ was strikingly different. In the case of 'Haden' fruit, only $2 \mathrm{kPa} \mathrm{O}_{2}$ among the low $-\mathrm{O}_{2}$ treatments maintained a larger hue angle than the air control after $5 \mathrm{~d}$ at $20^{\circ} \mathrm{C}$ (Fig. 3A), but epidermal chroma values were the same in the air control and low- $\mathrm{O}_{2}$-stored fruit (Fig. 3B). In contrast, 'Tommy Atkins' fruit from all the low $\mathrm{O}_{2}$ treatments maintained both larger epidermal hue angles and lower chroma values than the air control fruit after $5 \mathrm{~d}$ at $20^{\circ} \mathrm{C}$ (Fig. 3C and D). This residual inhibition of epidermal color development in 'Tommy Atkins' fruit after CA storage occurred despite rates of ethylene production at $20^{\circ} \mathrm{C}$ that were at least 2fold higher than for 'Haden' fruit (Figs. 1E and F). Interestingly, the flesh color of 'Tommy Atkins' mangoes (data not presented) was not affected by the CA treatments. There was also no effect of storage time on flesh color. At transfer from CA to air, the averages for all the CA treatments plus air control fruit were 90.37 \pm 0.68 for flesh hue and $57.03 \pm 1.65$ for chroma. After $5 \mathrm{~d}$ in air at $20^{\circ} \mathrm{C}$, the averages were $90.28 \pm 1.02$ and $56.93 \pm 1.84$ for flesh hue and chroma, respectively.

Tian et al. (1994) determined that the hue angle of 'Shogun' broccoli florets [Brassica oleracea L. (Italica Group)] changed in an ethylene dose-dependent decline. The authors determined that an ethylene concentration as low as $0.01 \mathrm{mg} \cdot \mathrm{L}^{-1}$ for $36 \mathrm{~h}$ at $20^{\circ} \mathrm{C}$ was enough to induce a $20 \%$ decrease in hue angle of the florets. Mangoes, in contrast to broccoli, have low levels of ethylene production (Burdon et al., 1996) and, while the fruit from the low$\mathrm{O}_{2}$ treatments in the present experiments produced ethylene at rates mostly below $0.1 \mu \mathrm{L} \cdot \mathrm{kg}^{-1} \cdot \mathrm{h}^{-1}$ for the duration of storage at 15 or $12^{\circ} \mathrm{C}$, i.e., 14 and $21 \mathrm{~d}$, respectively, changes in epidermal hue angles during this period were $<10 \%$ of the initial value, which could indicate that either ethylene action was suppressed or that mangoes have a higher ethylene threshold level for epidermal color development.

Inhibition of ethylene action was likely involved in the delay of epidermal color development in the CA-stored mangoes based on observations by Burg and Burg (1962), who determined that color development in 'Kent' and 'Haden' mangoes was synchronous with increasing ethylene production during the climacteric rise. The same concurrence was observed by Krishnamurthy and Subrahmanyam (1970) working with 'Pairi' mangoes and by Cua and Lizada (1990) working with 'Carabao' mangoes. The different responses of 'Haden' and 'Tommy Atkins' to CA in terms of color changes could be due to either cultivar or maturity differences in the threshold ethylene levels required for color changes to occur or in the sensitivity of ethylene action to inhibition by low $\mathrm{O}_{2}$ or high $\mathrm{CO}_{2}$. The 'Tommy Atkins' fruit may have been at a more advanced maturity stage than the 'Haden' mangoes as discussed below, but ethylene levels were similar during storage for both cultivars. Thus, the greater effect of low $\mathrm{O}_{2}$ during storage on the epidermal color of 'Tommy Atkins' compared to 'Haden' suggests that the former may require higher concentrations of ethylene to trigger color development. There was also a much greater residual effect of the CA treatments on epidermal color changes in 'Tommy Atkins' after transfer to air at $20{ }^{\circ} \mathrm{C}$, despite the higher ethylene production compared to 'Haden' mentioned above. It is possible that the ethylene signal pathway leading to color change was damaged irreversibly by the low $\mathrm{O}_{2}$ and $25 \mathrm{kPa} \mathrm{CO}_{2}$ storage treatments in 'Tommy Atkins'. The 25 $\mathrm{kPa} \mathrm{CO}_{2}$ treatment had a similar effect on the epidermal color development of both cultivars during storage. This may have been due to greater inhibition of ethylene biosynthesis by the high $\mathrm{CO}_{2}$ compared to low $\mathrm{O}_{2}$ (Bender et al., 1995) or to direct inhibition of ethylene action by the $\mathrm{CO}_{2}$ (Abeles et al., 1992) during the CA storage. However, the $25 \mathrm{kPa} \mathrm{CO}_{2}$ treatment was also generally more effective than low $\mathrm{O}_{2}$ in maintaining the epidermal color of the mangoes after transfer to air, when no residual effect of the $\mathrm{CO}_{2}$ treatment on ethylene production was apparent and when any direct effect of the high $\mathrm{CO}_{2}$ was no longer possible.

Ethanol is normally produced by ripening mango fruit, even in air (Bender et al., 2000). We have measured ethanol production rates as high as $2000 \mu \mathrm{L} \cdot \mathrm{kg}^{-1} \cdot \mathrm{h}^{-1}$ at $20^{\circ} \mathrm{C}$ by 'Tommy Atkins' mangoes held continuously in air for 2 weeks at $12^{\circ} \mathrm{C}$ plus $5 \mathrm{~d}$ at $20^{\circ} \mathrm{C}$ (Bender et al., 1994) without any indication of abnormal flavor development. In the present experiments with mature green 'Haden' and 'Tommy Atkins', there were no external or internal symptoms of injury in CA-stored fruit, and only the fruit held in $2 \mathrm{kPa} \mathrm{O}_{2}$ developed off flavor (data not presented). Ripening initiated 'Haden' mangoes produced much higher levels of ethanol than mature green 'Haden' fruit and, while the fruit still showed no visible injuries, off flavor developed after 2 weeks in both 2 and $3 \mathrm{kPa} \mathrm{O}_{2}$. However, it remains possible that the elevated ethanol levels in the mangoes from low- $\mathrm{O}_{2}$ storage described herein were involved in the residual inhibition of ripening after transfer to air at $20^{\circ} \mathrm{C}$. This possibility is supported by a comparison of the ethanol levels in mature green 'Haden' and 'Tommy Atkins' mangoes from the 2, 3, 4, and $5 \mathrm{kPa} \mathrm{O}_{2}$ treatments (Fig. 1C and D) with the hue angle values for those fruit (Fig. 3A and C), which show that color maintenance for the different treatments corresponded to the levels of ethanol production measured. The lack of a similar correlation between ethanol levels and color changes in the $25 \mathrm{kPa} \mathrm{CO}$-stored mangoes, which produced little ethanol but maintained color as well or better than the low- $\mathrm{O}_{2}$ treatments, suggests that different mechanisms may be involved in the inhibition of color changes in mangoes by low $\mathrm{O}_{2}$ and high $\mathrm{CO}_{2}$.

Different responses of 'Haden' and 'Tommy Atkins' mangoes to low $\mathrm{O}_{2}$ may be due to inherent cultivar differences. Another 
possibility is that maturity differences between the cultivars account for differences in behavior. 'Tommy Atkins' mangoes may have been more advanced physiologically than 'Haden' mangoes when entering CA storage, as indicated by epidermal hue angles of $103.4 \pm 2.8$ (less green) for 'Tommy Atkins' compared to $119 \pm 1.8$ (more green) for 'Haden'. In addition, the rates of ethylene production by 'Tommy Atkins' fruit after transfer to air at $20^{\circ} \mathrm{C}$ were several times higher than in 'Haden' fruit (Fig. 1E and F), which also suggests that the 'Tommy Atkins' fruit may have been at a more advanced stage of maturity than the 'Haden' fruit. A comparison of the results for preclimacteric and climacteric 'Haden' fruit clearly shows that ripeness stage affected the response to low $\mathrm{O}_{2}$ in terms of respiration and ethanol production (Fig. 1A and $\mathrm{C}$ vs. Fig. 2). Since the two cultivars used in this study came from different production areas, a third possibility is that different preharvest conditions or cultural practices may have influenced the responses to low $\mathrm{O}_{2}$ storage.

In conclusion, storage of mangoes in 2 to $5 \mathrm{kPa} \mathrm{O}_{2}$ at 12 or 15 ${ }^{\circ} \mathrm{C}$ induced various levels of ethanol production depending on cultivar and fruit maturity, but did not induce higher $\mathrm{CO}_{2}$ production typical of anaerobic metabolism. Based on induction of ethanol production, the low $\mathrm{O}_{2}$ limit for storage of mature green 'Haden' and 'Tommy Atkins' mangoes was only $4 \mathrm{kPa}$, however, there were no visible injury symptoms and only the fruit held in $2 \mathrm{kPa} \mathrm{O}_{2}$ developed off flavor within the time frame of these tests. Ripening initiated 'Haden' mangoes produced much higher levels of ethanol than mature green 'Haden' fruit and off flavor developed after 2 weeks in both 2 and $3 \mathrm{kPa} \mathrm{O}_{2}$. Low $\mathrm{O}_{2}$ had little effect on ethylene production, firmness or sugar levels in mature green mangoes, but inhibited color changes during storage at 12 or $15^{\circ} \mathrm{C}$, and $<5 \mathrm{kPa} \mathrm{O}_{2}$ maintained higher organic acid levels during ripening in air at $20^{\circ} \mathrm{C}$ for both cultivars. Storage in $25 \mathrm{kPa}$ $\mathrm{CO}_{2}$ did not induce ethanol production, and was more effective than low $\mathrm{O}_{2}$ in maintaining fruit epidermal color following transfer to air at $20^{\circ} \mathrm{C}$. We conclude that mature green 'Haden' and 'Tommy Atkins' mangoes can tolerate $3 \mathrm{kPa} \mathrm{O}_{2}$ for 2 or 3 weeks at 12 or $15^{\circ} \mathrm{C}$. Our results indicate a potential for using low $\mathrm{O}_{2}$ atmospheres to help maintain quality and slow ripening during marine transport of mangoes.

\section{Literature Cited}

Abeles, F.B., P. W. Morgan, and M.E. Saltveit, Jr. 1992. Ethylene in plant biology. Academic, San Diego.

Beaudry, R.M., A.C. Cameron, A. Shirazi, and D.L. Dostal-Lange. 1992. Modified-atmosphere packaging of blueberry fruit: Effect of temperature on package oxygen and carbon dioxide. J. Amer. Soc. Hort. Sci. 117:436-441.

Bender R.J., J.K. Brecht, E.A. Baldwin, and T.M.M. Malundo. 2000. Aroma volatiles of mature-green and tree-ripe 'Tommy Atkins' mangoes after controlled atmosphere vs. air storage. HortScience 35:684686.

Bender R.J., J.K. Brecht, and C.A. Campbell. 1994. Responses of 'Kent' and 'Tommy Atkins' mangoes to reduced $\mathrm{O}_{2}$ and elevated $\mathrm{CO}_{2}$. Proc. Fla. State Hort. Soc. 107:274-277.

Bender R.J., J.K. Brecht, and S.A. Sargent. 1995. Inhibition of ethylene production in mango fruit by elevated $\mathrm{CO}_{2}$ and recovery during subsequent air storage. Proc. Fla. State Hort. Soc. 108:279-285.

Bergsma K.A. and J.K. Brecht. 1992. Postharvest respiration, moisture loss, sensory analysis and compositional changes in jicama (Pachyrrhizus erosus) roots. Acta Hort. 318:325-332.

Boersig, M.R., A.A. Kader, and R.J. Romani. 1988. Aerobic-anaerobic respiratory transition in pear fruit and cultured pear fruit cells. J. Amer.
Soc. Hort. Sci. 113:869-873.

Burdon, J., S. Dori, R. Marinanski, and E. Pesis. 1996. Acetaldehyde inhibition of ethylene biosynthesis in mango fruit. Postharvest Biol. Technol. 8:153-161.

Burg, S.P. and E.A. Burg. 1962. Role of ethylene in fruit ripening. Plant Physiol. 37:179-189.

Cua, A.U. and M.C.C. Lizada. 1990. Ethylene production in the 'Carabao' mango (Mangifera indica L.) fruit during maturation and ripening. Acta Hort. 269:169-178.

Dubois M., K.A. Gilles, J.K. Hamilton, P.A. Rebers, and F. Smith. 1956. Colorimetric method for determination of sugars and related substances. Anal. Chem. 31:796-801.

Gull, D.D. 1987. A simplified firmness tester for horticultural products. HortScience 22:1146 (abstr.).

Hamson, A.R. 1952. Measuring firmness of tomatoes in a breeding program. Proc. Amer. Soc. Hort. Sci. 60:425-433.

Johnson, G.I., J.L. Sharp, D.L. Milne, and S.A. Oosthuyse. 1997. Postharvest technology and quarantine treatments, p. 447-507. In: R.E. Litz (ed.). The mango: Botany, production, and uses. CAB Intl., Wallingford, U.K.

Ke, D., T. El-Sheikh, M. Mateos, and A.A. Kader. 1993. Anaerobic metabolism of strawberries under elevated and reduced atmospheres. Acta Hort. 343:93-99.

Ke, D., E. Yahia, B. Hess, L. Zhou, and A.A. Kader. 1995. Regulation of fermentative metabolism in avocado fruit under oxygen and carbon dioxide stresses. J. Amer. Soc. Hort. Sci. 120:481-490.

Kennedy, R.A., M.E. Rumpho, and T.C. Fox. 1992. Anaerobic metabolism in plants. Plant Physiol. 100:1-6.

Krishnamurthy, S. and H. Subrahmanyam. 1970. Respiratory climacteric and chemical changes in the mango fruit, Mangifera indica L. J. Amer. Soc. Hort. Sci. 95:333-337.

McGuire, R. 1991. Concomitant decay reductions when mangoes are treated with heat to control infestations of Caribbean fruit flies. Plant Dis. 75:946-949.

McGuire, R. 1992. Reporting of objective color measurements. HortScience 27:1254-1255.

Medlicott, A.P., J.M.M. Sigrist, and O. Sy. 1990. Ripening of mangoes following low-temperature storage. J. Amer. Soc. Hort. Sci. 115:430 434.

Miller, W.R., D.H. Spalding, and P.W. Hale. 1986. Film wrapping mangos at advancing stages of post-harvest ripening. Trop. Sci. 26:917.

Nyanjage, M.O., H. Wainwright, and C.F.H. Bishop. 1998. The effects of hot-water treatments in combination with cooling and/or storage on the physiology and disease of mango fruits (Mangifera indica Linn.). J. Hort. Sci. Biotechnol. 73:589-597.

Thompson, A.K. 1998. Controlled atmosphere storage of fruits and vegetables. CAB Intl., Wallingford, U.K.

Tian, M.S., C.G. Downs, R.E. Lill, and G.A. King. 1994. A role for ethylene in the yellowing of broccoli after harvest. J. Amer. Soc. Hort. Sci. 119:276-281

U.S. Department of Agriculture. 1998. Plant protection and quarantine treatment manual (T102a). U.S. Dept. Agr., Govt. Printing Office, Wash., D.C.

Yahia, E.M. 1998. Modified and controlled atmospheres for tropical fruits. Hort. Rev. 22:123-183.

Yahia, E.M, F. Medina, and M. Rivera. 1989. The tolerance of mango and papaya to atmospheres containing very high levels of $\mathrm{CO}_{2}$ and/or very low levels of $\mathrm{O}_{2}$ as a possible insect control treatment, p. 77-89. In: J.K. Fellman (ed.). Proc. 5th Intl. Controlled Atmosphere Res. Conf. vol. 2. Wenatchee, Wash.

Yahia.E.M. and M. Tiznado-Hernandez. 1993. Tolerance and responses of harvested mango to insecticidal low-oxygen atmospheres. HortScience 28:1031-1033.

Yahia, E.M. and L. Vazquez-Moreno. 1993. Responses of mango to insecticidal oxygen and carbon dioxide atmospheres. Food Sci. Technol. (Lebensm. Wiss. U-Technol.) 26:42-48. 